\title{
Putting human rights at the heart of social work practice
}

Neil Ballantyne, Open Polytechnic of New Zealand

This commentary was published by the Aotearoa New Zealand Association of Social Workers (ANZASW) on the occasion of International Human Rights Day, 10 December 2019. ANZASW invited the author to respond to several questions on the topic of human rights. In 2019, Neil was the inaugural winner of the John Fry Memorial Supreme Award for Quality and Innovation in Social Work for his work as a Palestinian human rights defender. The article is structured in a question and response format.

\section{How are human rights connected to social work?}

Human rights are central to social work (Ivory, 2017; Truell, 2016) and being a human rights defender (OHCHR, 2004) ought to be a primary motivator and goal. The global definition of social work includes reference to "principles of social justice, human rights, collective responsibility and respect for diversities" (IFSW, 2014) and there is even an international journal dedicated to the topic: the Journal of Human Rights and Social Work (Gatenio Gabel \& Mapp, 2016). Here in Aotearoa, core competence standard four states that social workers must be competent to "promote the principles of human rights, and social and economic justice" (SWRB, 2015, Standard Four); and the code of ethics of the Aotearoa New Zealand Association of Social Workers (ANZASW, 2019, p. 9) "is committed to respecting the dignity of every person as the foundation of its ethical principles, and to national and international codes of human rights."

Of course, it is one thing to make statements that highlight human rights, but quite another to take concrete actions that promote or protect them. No one in the world, not even the most ruthless dictator, will say they are against human rights; and yet many governments and organisations, including health and social work organisations, routinely take actions that transgress human rights. The main statement of human rights was set out in the United Nations (UN) Universal Declaration of Human Rights (UN, 1948) but the declaration needs to be read in conjunction with several subsequent treaties and conventions that expand on rights for particular groups and peoples: such as the 1979 Convention on the Elimination of All Forms of Discrimination against Women (CEDAW), the 1989 Convention on the Rights of the Child (CRC) and-especially important for Aotearoathe 2007 UN Declaration on the Rights of Indigenous Peoples (UNDRIP).

Human-rights-based approaches to social work are sometimes contrasted with needsbased approaches (Mapp, McPherson, Androff, \& Gatenio Gabel, 2019). Needsbased approaches are associated with an individualistic, case-based orientation based on clinical or deficit models of practice. Needs-based approaches tend to characterise social workers as experts who intervene to promote the wellbeing of people in need. Rights-based approaches, on the other hand, emphasise the common humanity of social workers and service users. Rights-based approaches promote the dignity and worth of all people and encourage bottom-up practice that empowers individuals, families and collectives (Ife, 2012). Strength-based perspectives and partnership working is encouraged. From this point of view, people who use social work services are considered 
experts by virtue of their experience (Preston-Shoot, 2007).

Of course, these two approaches can, and should, be blended. Human rights' violations that emanate from structural sources-such as system violence, economic injustice, patriarchy or colonisation-should be articulated and challenged as macro-level issues, but the immediate micro-level impact on individuals and families also needs to be recognised and ameliorated. The classical "person in environment" perspective is critical, but must be practised in a genuinely integrated way (Kondrat, 2002). Too often, a concern to ameliorate issues for individuals considered to be "vulnerable" leads social workers to neglect macro issues and evendirectly or indirectly - to blame individuals and families for their predicament, thus further alienating them from achieving their human rights.

\section{Can you describe your activities on human rights and the kaupapa that guides these actions?}

As a social work educator, I am responsible for ensuring that future social workers understand human-rights perspectives on social work and I teach courses on human rights, social justice, working with communities, and social work law and ethics. As a social work researcher, an awareness of human rights informs my practice and I have worked with colleagues to investigate the teaching of social justice and human rights across the curriculum. Recently, in a project involving the co-design of a capability framework for newly qualified social workers, we ensured the framework included a capability statement on social justice and human rights (Ballantyne et al., 2019).

\section{CAPABILITY THREE: Manatika | Social justice}

Social workers understand the sources of social inequity and are capable of taking actions to protect and advocate for human rights including civil, political, environmental, economic, social and cultural rights. Social workers recognise the impact of social structural factors on the lives of people-such as poverty, racism, poor housing and social exclusion-and are capable of working with people at micro, meso and macro levels to prevent stigmatisation and promote social change. They understand the global interconnections of oppression and human rights violations and are knowledgeable about theories of human need, social justice and strategies to promote social, economic and environmental justice and human rights. Social workers promote strengths, agency, hope and self-determination. (Ballantyne et al., 2019, p. 30)

Outside of my work role, one of my main preoccupations is with the human rights of Palestinian people and I am an activist and co-convenor of a local group called Wellington Palestine. Israel's military occupation of Palestine has continued for over half a century and the oppression of the Palestinian people is the longest-standing, unresolved issue for the United Nations. It is a strange paradox that the $\mathrm{UN}$, an organisation founded as a direct result of the horror of the holocaust, by supporting the partition of Palestine into two states, created the conditions for one of the most repressive regimes in human history. Although the UN

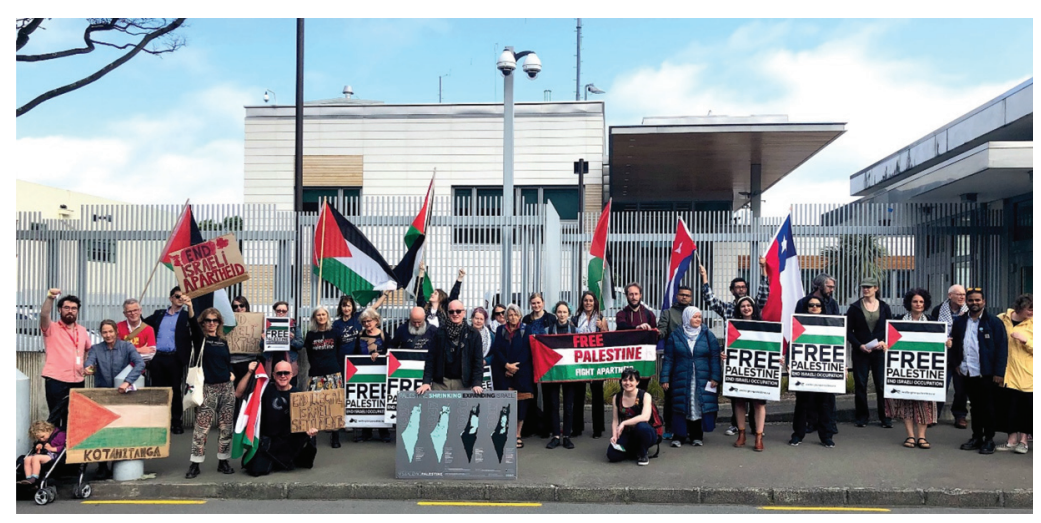

Figure 1. Neil leading a protest outside the US Embassy in Wellington on International Day of Solidarity with the Palestinian People. 


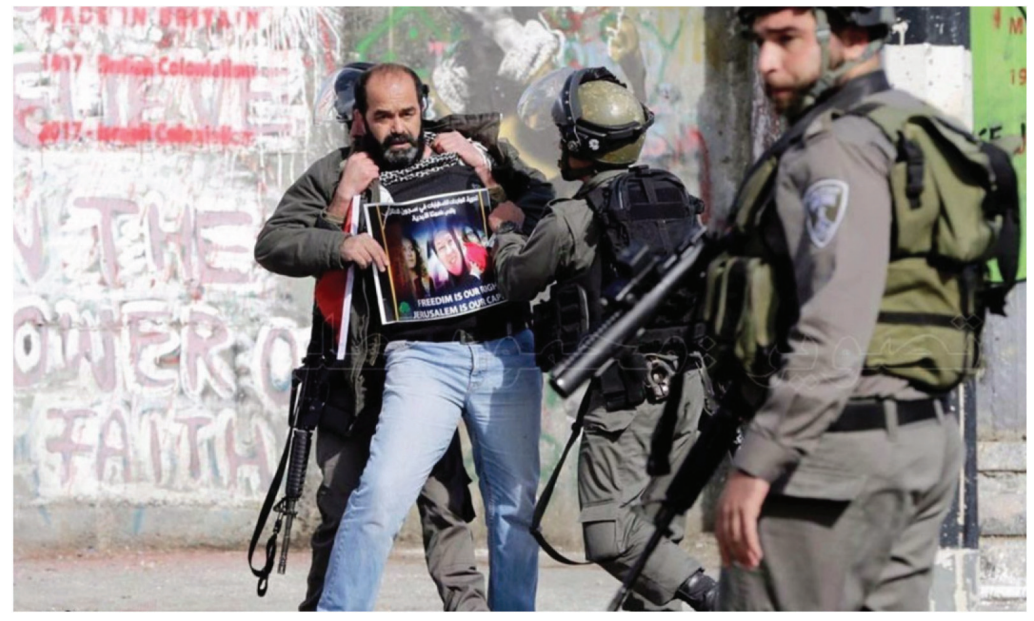

Figure 2. The Palestinian social worker, Munther Amira, is arrested by Israeli forces during a peaceful protest to defend the rights of Palestinian child prisoners.

recognises the aspirations of the Palestinian people, and repeatedly declares many of the actions of Israel to be illegal under international law, so long as the US has a veto on the security council, it is powerless to intervene.

Wellington Palestine works in partnership with other Palestinian rights groups across Aotearoa. I am involved in this activity as a volunteer outside of work, yet it is intimately connected to my professional work since it was the arrest and detention of the Palestinian social worker, Munther Amira, that triggered my involvement with the Palestine solidarity movement. I wrote a paper with Raed Amira, a social worker working in the Aida refugee camp in Bethlehem, on Munther's arrest and the plight of Palestinian child prisoners: a topic that will be the main focus for Wellington Palestine's campaigning activity in the new year (Amira, Ballantyne, \& Duarte, 2018).

\section{Can you describe some of the social work roles that are most intimately connected to HR?}

Some social work roles might seem more directly related to human rights work than others. So, any social worker whose main activity concerns advocacy is almost certainly working in the domain of human rights. However, if you read the 29 articles of the Universal Declaration of Human Rights (and these should be on wall of the office of every social worker in the country), it is hard to imagine any social work role that is not connected to the promotion and protection of human rights: the right to an education; the right to life, liberty and security; the right not to be subjected to torture or to cruel, inhuman or degrading treatment or punishment; full equality to a fair and public hearing by an independent and impartial tribunal; the right to work; the right to a standard of living adequate for health and well-being, including food, clothing, housing and medical care and many more. A careful reading of those rights, and the rights captured in related conventions and treaties-especially UNDRIP — highlights just how far we have to travel to protect and achieve human rights even in a relatively wealthy, liberal democracy like Aotearoa New Zealand.

\section{Why are human rights important in challenging neoliberalism and improving social outcomes? How can they be used in concrete, practical ways to improve the lives of marginalised people and to change society for the better?}

Forty years of neoliberalism have had a devastating impact on communities, on the environment, and on human rights worldwide (Monbiot, 2016). Inequality has deepened, oppressive working conditions and precarity are pervasive, and everywhere people feel disempowered and disconnected. The competitive, individualistic ethos of the neoliberal order actively undermines human solidarity and the dignity and worth of all people (Garrett, 2019). Austere social policies have rolled back welfare provisions, undermining the health and social welfare safety net and dismantling state involvement in housing services. From a global perspective, the "war on terror," Islamophobia and the rise of far-right groups 
has added pressure to refugee and migrant populations displaced by war and repressive regimes. As Sewpaul (2016, p. 32) has highlighted, "within the [global] neoliberal framework":

...social and economic exclusions are fostered by the process of othering, based on criteria such as "race", religion, ethnicity, nationality, sexuality and gender, and refugees and asylum seekers are deemed to be the undeserving other, which is accentuated in the existing climate of global terrorism and Islamophobia.

In this context, a renewed emphasis on human rights and social justice within social work becomes a rallying point to challenge neoliberalism and repressive regimes. In many countries, especially those governed by oppressive elites, people have taken to the streets to resist. Today there are examples of spontaneous, popular resistance movements in Chile, Bolivia, Hong Kong, Iraq, Iran and many more (Ehrenreich, 2019). These popular movements are often triggered by demands for basic human rights to life, liberty and security; and, when the movements are met with repressive police or military forces, other rights come into play: freedom of expression, freedom of assembly, not being subject to arbitrary arrest or detention. Social workers and social work organisations are often at the forefront in defending human rights in these situations; see, for example, the recent statement by the Hong Kong Association of Social Workers (IFSW, 2019, November 13).

The intentions of those who drafted the Universal Declaration of Human Rights were to establish a benchmark for rights that were held to be universal - they belong to all of us, to everybody in the world; inalienable - they cannot be taken away from us; and indivisible and interdependent-that is, governments should not be able to pick and choose which are respected. Sadly, governments throughout the world routinely ignore and breach the human rights of their people.
Which is why we need agreed statements of universal human rights, and human rights defenders-including social workers-who will take resolute action to promote and protect them (sometimes at considerable risk to their own personal safety, health and wellbeing, especially under conditions of military occupation, or during periods of repressive police action (Lavalette \& Ioakimidis, 2011)).

Social workers in Aotearoa New Zealand should be should be aware of our own human rights provisions including the Bill of Rights Act 1990, the Human Rights Act 1993 and the work of the Human Rights Commission. However, the fullest achievement of all our human rights (social, economic and cultural as well as civil and political) needs more than narrow, legalistic enforcement; it requires education, solidarity, collective action and transformational social change.

Some might wonder why social workers should be concerned about the rights of people overseas when so many issues confront us here at home. It is true that there are human right abuses, historical and current, right here in Aotearoa New Zealand. We only have to consider the current debates about the rights of Māori in relation to our child protection system (Hyslop, 2019), or reproductive rights (Beddoe, 2019), or disputed land rights (Darroch, 2019) or the rights of people in prison (Cox, 2018). In Aotearoa the Reimagining Social Work blog has emerged as an excellent medium for social work educators, students and practitioners to write and reflect on issues of social justice and human rights and to bring attention to the collective actions-petitions, protests, and direct action-that community groups are taking to advance those rights.

However, the promotion and protection of human rights is, fundamentally, an international issue that recognises the need for human solidarity across borders. In Aotearoa New Zealand, we are relatively free to organise, to assemble and to 
campaign for our rights. I have no doubt that if I were doing in Bethlehem (the most tear-gassed town on the planet) the work that I do as an activist in Wellington, I would be arrested and detained like my colleague Munther Amira. Perhaps worse.

So, I choose to use my freedom to work for the rights of the thousands of Palestinian people - including hundreds of children who are prosecuted in military courts and incarcerated in Israel's jails (Addameer, 2019). Military rule disrupts every aspect of daily life in occupied Palestine. Palestinians are denied the most basic of human rights that New Zealanders take for granted, including freedom of movement, freedom of association and freedom of speech. Through its so-called "security measures"-including the separation wall and network of military checkpointsPalestinian men, women and children are subject to daily humiliations and held captive in a system that is as oppressive as the former South African apartheid state (ESCWA, 2017). Nelson Mandela (1997) famously declared that "our freedom is incomplete without the freedom of the Palestinian people." For me, that is a call to struggle relentlessly until all Palestinians - whether living in exile, as citizens of Israel or in the occupied territoriesachieve their inalienable human rights.

\section{References}

Addameer. (2019). Statistics: October, 2019. Retrieved from https://www.addameer.org/statistics

Amira, R., Ballantyne, N., \& Duarte, F. (2018). Promoting the empowerment and liberation of people in Palestine. Critical and Radical Social Work, 6(1), 119-122.

Aotearoa New Zealand Association of Social Workers (ANZASW). (2019). Code of ethics. Retrieved from https://anzasw.nz/wp-content/uploads/ANZASWCode-of-Ethics-Final-1-Aug-2019.pdf

Ballantyne, N., Beddoe, L., Hay, K., Maidment, J., Walker, S., \& Merriman, C. (2019). Enhancing the readiness to practice of newly qualified social workers in Aotearoa New Zealand. Report on phase three: The professional capabilities framework. Wellington, New Zealand: Ako Aotearoa. Retrieved from https://ako.ac.nz/knowledgecentre/enhancing-the-readiness-to-practice-of-newlyqualified-social-workers/

Beddoe, L. (2019, August 17). Time for social work to make a clear stand for abortion law reform [Web log post]. Retrieved from http://www.reimaginingsocialwork. nz/2019/08/time-for-social-work-to-make-a-clear-standfor-abortion-law-reform/
Economic and Social Commission for Western Asia (ESCWA). (2017). Israeli practices towards the Palestinian people and the question of apartheid Palestine and the Israeli occupation, Issue No. 1. Beirut, Lebanon: United Nations. Retrieved from https://electronicintifada.net/sites/default/files/2017-03/ un_apartheid_report_15_march_english_final_.pdf

Cox, K. (2018, March, 10). Professionals against prisons Aotearoa [Web log post]. Retrieved from http://www.reimaginingsocialwork.nz/2018/03/ professionals-against-prisons-aotearoa/

Darroch, J. (2019, July 27) Ihumātao [Web log post]. Retrieved from http://www.reimaginingsocialwork. nz/2019/07/ihumatao/

Ehrenreich, B. (2019, November 25). Welcome to the global rebellion against neoliberalism. Retrieved from: https://www.thenation.com/article/global-rebellionsinequality/

Gatenio Gabel, S., \& Mapp, S. (2016). Editorial. Journal of Human Rights and Social Work, 1(1), 1-2.

Hyslop, I. (2019, December 6). Re-imagining devolution: Puao-te-ata-tu revisited. [Weblog post]. Retrieved from http://www.reimaginingsocialwork.nz/2019/12/reimagining-devolution-puao-te-ata-tu-revisited/

Ife, J. (2012). Human rights and social work: Towards rights-based practice (3rd ed.). Cambridge, UK: Cambridge University Press

International Federation of Social Workers. (2014). Global definition of social work. Retrieved from https://www.ifsw. org/what-is-social-work/global-definition-of-social-work/

International Federation of Social Workers. (2019, November 13). Social workers call for international solidarity as violence escalates in Hong Kong. Retrieved from https://www.ifsw.org/hong-kong-social-workersassociation-statement-on-extradition-bill/

Ivory, M. (2017, May). Should human rights top the social work agenda? The Guardian. Retrieved from https://www.theguardian.com/social-care-network/2017/ may/24/human-rights-social-work

Kondrat, M. E. (2002). Actor-centered social work: Revisioning "person-in-environment" through a critical theory lens. Social Work, 47(4), 435-448.

Lavalette, M., \& loakimidis, V. (Eds.). (2011). Social work in extremis: Lessons for social work internationally. Bristol, United Kingdom: Polity Press.

Mandela, N. (1997). Address by President Nelson Mandela at the International Day of Solidarity with the Palestinian People. Retrieved from http://www.sahistory.org.za/ archive/address-president-nelson-mandela-internationalday-solidarity-palestinian-people-pretoria-4

Mapp, S., McPherson, J., Androff, D., \& Gatenio Gabel, S. (2019). Social work is a human rights profession. Social Work, 64(3), 259-269.

Monbiot, G. (2016, April 15). Neoliberalism: The ideology at the root of all our problems. Retrieved from https://www.theguardian.com/books/2016/apr/15/ neoliberalism-ideology-problem-george-monbiot

Office of the United Nations High Commissioner for Human Rights. (2004). Human rights defenders: Protecting the right to defend human rights, Fact sheet 29. Geneva, Switzerland: United Nations. Retrieved from https://www.ohchr.org/Documents/Publications/ FactSheet29en.pdf 
Preston-Shoot. M. (2007). Whose lives and whose learning? Whose narratives and whose writing? Taking the next research and literature steps with experts by experience. Evidence and Policy, 3(3), 343-359.

Sewpaul, V. (2016). The west and the rest divide: Human rights, culture and social work. Journal of Human Rights and Social Work, 1(1), 30-39.

Social Workers Registration Board. (2015). The SWRB ten core competence standards. Wellington: Author. Retrieved from https://swrb.govt.nz/for-social-workers/ competence/core-competence-standards/

Truell, R. (2016, December 9). It is time to focus on the rights at the heart of social work. Retrieved from https://www.theguardian.com/social-care-network/2016/ dec/09/it-is-time-to-focus-on-the-human-rights-at-theheart-of-social-work

United Nations. (1948). The universal declaration of human rights. Retrieved from https://www.un.org/en/universaldeclaration-human-rights/ 